\title{
Deciphering the Democratic People's Republic of Korea
}

John Hemmings

London School of Economics, London, UK

Victor, Cha

The Impossible State: North Korea, Past and Future. Harper Collins: New York, 2012, 530pp., \$29.99, ISBN 978-0-06-199850-8

Ken E. Gause

North Korea under Kim Chong-Il: Power, Politics, and Prospects for Change. Praeger Security

International: Santa Barbara, CA, 2011, 231pp., \$42.70, ISBN 978-0-313-38175

Andrei, Lankov

The Real North Korea: Life and Politics in the Failed Stalinist Utopia. Oxford University Press: Oxford, UK, 2013, 283pp., \$27.95, ISBN 978-0-19-996429-1

Kyung-Ae, Park and Scott Snyder (eds.)

North Korea in Transition. Rowman \& Littlefield Publishers: Plymouth, UK (Kindle Version), 2013, 307pp., \$34.99, ISBN 978-1-4422-1813-0

James G. Zumwalt

Living the Juche Lie: North Korea's Kim Dynasty. US Adducent: Florida (Kindle Version), 2012, 180pp., \$3.99, ISBN 978-1937592-18-9

Abstract I North Korea remains puzzling to many in the West. Understanding of the regime, its social system, and its people is clouded by the role it plays in regional security. The annual nature of its crises, the severity of its system, and the belligerence of its diplomacy, all serve to obscure key elements of the state, including its internal politics and economy. A number of scholars and policy makers have attempted to shine light on these areas, with some limited success.

International Politics Reviews (2013) 1, 65-77. doi:10.1057/ipr.2013.7;

published online 12 December 2013

Keywords: North Korea; DPRK; East Asia; Pyongyang; Security; songbun

\section{Introduction}

Over the years, North Korea has probably received more crisis news coverage in the global media than any other country. This is due partly to the nature of the situation on the Korean Peninsula - a frozen conflict - and the incremental development by the North of nuclear weapons. 
Counted as one crisis, it has lasted nearly 20 years, since North Korea threatened to withdraw from the NonProliferation Treaty in 1993. Often as not, much of media coverage of North Korea seems to obscure the nature of the regime rather than shed light on it. The dominance of the security narrative prompted by the annual cycle of missile launches, nuclear tests and other provocations shoulders aside narratives on human rights, economic reform and North Korean societal issues. Certainly those issues get a mention by popular media, but this is usually merely as reference points to the larger security narrative. This monopoly that the security narrative has on the popular media shapes the view and work of various Western agencies of government, think tanks and, of course, academia. The introverted and isolated nature of North Korean society and its inability to mobilize Western media to its own narratives mean that the country has long been reduced to generalization and best-guess analysis of the regime. As Lankov states, 'for the vast majority of Americans and Europeans, North Korea is a nuclear device' (Lankov, 2013, p.146).

This tendency to characterize North Korea as monolithic is seemingly justified by its totalitarian nature. It is difficult, if not impossible, to treat social and political issues separately from, say, military issues in the North Korean context, largely because of the blur between civilmilitary sectors in the country (Armstrong, 2012; Park and Snyder, 2013). The army is a mobilizer of human capital, a large part of the economy and a shaper of security-nationalist narratives. Such regimes are difficult to study without some bias. With the world's worst record of human rights, it is difficult if not impossible for Western scholars and experts to study the country without some emotive response. ${ }^{1}$ How can one be impartial or objective about a state that continues to run gulags and death camps? The totalitarian completeness of the state and the 'insidious' coercive and ideational tools for population control go completely against long-cherished liberal-democratic beliefs about the individual and the relationship between governors and governed. Rousseau's social contract is based on two parties knowingly forming a covenant. In the North Korean case, the population is apparently unknowing, making it difficult to know whether acceptance is the same thing as support for the regime. Does this undermine the sovereignty and legitimacy of the regime? While understandable, this cultural debate adds to the muddle that characterizes analysis of the regime and distorts policy choices.

Fortunately for those who wish for a deeper analysis of North Korea, there is a growing canon of work that sheds light on the nature of the regime, some of which is reviewed in this study. As Charles Armstrong contends, little of this literature can be considered 'scholarship', given the paucity of evidence, and rigorous methodology involved in analysis of the country (Armstrong, 2012).
Instead, work on North Korea tends to be a patchwork of research, anecdotal events and personal accounts by think tank officials, former government officials and North Korea 'experts' within academia. Although this study only focuses on English language-based studies, there are other Democratic People's Republic of Korea (DPRK)-related literatures within the Japanese, Chinese and Korean academic communities, which are not dealt with here. The books in this review essay were selected for this study based on the timeliness of the publication, and this review deliberately seeks the latest analysis of North Korea in light of the latest writing and the changes that have affected the country over the past 2 years. Only Guase's North Korea under Kim Chong-Il: Power, Politics, and Prospects for Change is from prior to 2012 and was mainly included because of its sharp focus on internal affairs inside the regime. His analysis is well informed by large numbers of interviews of defectors, including of Hwang Chang-yop, ${ }^{2}$ which gives motivation and character to the Kim family and their top advisors.

Andrei Lankov is well known among Korea-watchers. His Russian background informs his latest book The Real North Korea: Life and Politics in the Failed Stalinist Utopia. He sees the internal dynamics of the country in a way that few Americans or South Koreans can match: he understands not only the Stalinist elements of the DPRK system, but its deviation from Kruschev's post-Stalinist USSR. His insights on how the country's probable collapse should be managed seem to come directly from the experience from his own country's history and times. James Zumwalt's Living the Juche Lie: North Korea's Kim Dynasty and Victor Cha's The Impossible State: North Korea, Past and Future are both American reactions to North Korea. Zumwalt's personal experience of the country (more than 10 trips) strengthens the sense of moral outrage that pervades his analysis. This arises from his firm stance in the liberal democratic tradition, which informs his understandable - even necessary - reaction to the regime. He shines a light on the impact of the regime on the ordinary life of the average North Korean and critques the regime's approach to power in a very clear and succinct manner. Cha's background as the Director of Asian Affairs in Bush's National Security Council (2004-2007) gives his work increadible insight into US policy making around the North. He is the only author reviewed who has a foot in both the academic and policy worlds, and this blend informs his analysis with policy detail understanding and anecdotal events of someone who has sat at the top tables with the North. His work on the Six Party Talks is essential reading. Finally, Park Kyung-Ae and Scott Snyder's North Korea in Transition is a compendium of essays on the regime-in-transition. It is a solid collection of essays, but particular attention should be paid to the economic chapter, the ideologial chapter and the political chapter. 
Nearly all authors represented in this review agree that North Korea is indeed a riddle, but most argue that it can be explained by understanding its internal logic and the historical-cultural factors that lead to that logic. Interestingly, they all agree with the thesis that its economic failures are not merely the accident of its political system, but the direct result of the system. Cha, Lankov and Eberstadt are clear that in Pyongyang, politics trumps economics, with dire consequences. Its ideal of self-sufficiency mixed with a top-heavy centrally planned economy doomed the economic chances of the country from the very start. Although all authors accept that the regime has tried bouts of reform, they believe these efforts to be half-hearted, with the regime doing little to correct itself. Why, then, has the North not followed the example of its communist benefactors in Moscow and Beijing by either collapsing or truly accepting economic reform? Gause, Lankov and Cha agree that reforms have always been half-hearted because they are seen as a backdoor to political liberalization. Liberalization means the loss of political control, which could lead to dire consequences for the regime. Zumwalt breaks away with the original suggestion that the regime may not have planned the famine, but that the government learned how to make even hunger a tool of control (Zumwalt, 2012, p.233). This use of hunger as a tool of social manipulation resonates with the permanent state of war used in Orwell's novel 1984 for social control.

Over the course of the review, I will examine three facets of North Korea examined by the literature, which correspond roughly to politics, economics and security. Since all five works in this review carry out varying degrees of analysis on roughly similar subjects, there is a great deal of overlap. For that reason, this review will proceed along a thematic basis, and examine the varying strands, arguments and theses put forward by the reviewed works. Where they correspond, I will offer a brief analysis, and where they differ, I will attempt a breakdown of varying arguments, and their strengths and weaknesses.

\section{Surviving Against the Odds}

Despite repeated predictions of collapse, North Korea continues to survive not only economic calamity, but also an increasingly unfavorable international situation. ${ }^{3}$ The literature surveyed in this review looks at that survival from both internal and external stresses. Politically and socially, North Korea is unusual as a political construct, with an extreme cult of leadership and highly indoctrinated social system. Accordingly, the inability to reform necessitates the nuclear programme as a major means of coercing the United States and its allies into bankrolling the regime. This view - commonly referred to as 'nuclear blackmail' in the popular press $^{4}$ - gets a historical analysis by Lankov, who looks carefully at the 1994 Agreed Framework and notes how it set the trend for US-DPRK relations. Both Cha and Lankov attempt to suggest policy-guidelines for escaping from this behaviour trap, but with varying degrees of success. Cha also points out that the decision to develop nuclear weapons has also become a strong symbol in the nationalist narrative of the Kim family, enabling it to maintain its supremacy over other agencies within the state. It was the weapon by which it could bind potential moderates to the nationalist cause.

\section{Setting the Stage}

It is impossible to do any sort of political analysis without reference to history and culture. Indeed, in North Korea's case, that nod is a very heavy one. There is simply no way of understanding North Korea's economic choices, its ideology, or its foreign and security policy without understanding the history of the Korean Joseon Dynasty, its fall to Japanese imperialism (1905), the subsequent colonization by Japan (1910-1945), and the mindset that has been engendered in the people of the North. In many ways, the beginnings of Korean nationalism begin much further back in time, with the three Kingdoms, and their competition for leadership of the peninsula. This, added to centuries of Chinese political influence and encroachment, has spawned a hyper-national identity, which has been shaped and strengthened by the transgressions of Korea's neighbours. Although Koreans broadly accepted the limited suzerainty under the Chinese Tributary system under the T'ang Dynasty, it was the rise of Shogunate Japan, and its seventeenth-century efforts to invade and occupy the Korean peninsula, that shaped the Korean peninsula with the themes of 'survival, endurance and resistance to foreign forces' (Snyder, 1999 p.20). This mentality was reinforced by the subsequent efforts of first Russia and then Japan to wrestle the country from China. Japan's victory over Russia and China for the Peninsula and its brutal colonial administration of Korea are often used by the North to describe the US relationship with the South. In this way, Pyongyang attempts to brand itself as the 'true' Korea.

In the North Korean education system, Kim Il-sung's role as an anti-Japanese guerrilla is amplified, so that the war in the Pacific becomes the war between China, Korea and Japan. Seen from Pyongyang, the North won the war against the Japanese, and their dream of uniting Korea under a worker's banner was wrecked by an opportunistic American invasion and occupation. It is a startling fact that most North Koreans to this day believe that South Korea started the war in 1950 at American prompting. (Declassified Soviet and PRC-era archives reveal Kim Il-sung's planning and requests for support from both Mao and Stalin in the months running up to the conflict.) Despite its own reliance on the Communist Bloc, the North has attempted to portray itself as the true holder of Koreaness, 
branding the South as 'unpatriotic' 'underdogs' who are controlled by their American (read foreign) masters, and gives the regime a brilliant weapon for the minds of their own public. As Zumwalt (2012) states, this also explains how the regime was able to maintain the support of the North Korean people. As bad as things got under the Kims, it 'still represented a step up from that experienced under the Japanese'. A Korean leader had repaired the national dignity and broken spirit and provided the people with a sense of accomplishment. Seen in this light, the development of a nuclear weapon was not only a right of the Korean people, but an obligation.

A final riddle avoided by much of the literature poses the question: What to do about North Korea if it does indeed collapse? Some argue that it would present the world with its largest humanitarian disaster, with large refugee movements towards both of the country's borders. Its large supply of chemical and bio-weapons - and the possibility that these might end up on global black markets - intensifies the urgency behind such speculation. The riddles inherent in any study of North Korea are such that one is tempted to paraphrase Lord Palmerston about the origins of the Schleswig-Holstein issue in nineteenthcentury Europe: 'The (North Korea) question is so complicated, only three men ... have ever understood it. One ... is dead. The second ... became mad. I am the third and I have forgotten all about it'.

\section{Politics, Ideology and Society}

It is not only possible to treat North Korea's political and social system together; it is necessary since they are tightly integrated. Indeed, they are so intermeshed that it is impossible to analyze one without reference to the other. This unity of political purpose and social structure finds its roots in the ideology itself, and the totalitarian nature of the regime.

For scholars of political science, North Korea is a classification riddle. It is after all an extreme example of the political construct known as the authoritarian regime. However, it is not just any authoritarian regime. It is, according to Victor Cha, 'the hardest of hard regimes in the world' (Cha, 2012, p.442). Like other authoritarian regimes, it has a high level of state control over its population and the information to which they have access. Although many Sovietologists often point to the similarities between other Eastern Bloc regimes, such comparisons are unhelpful. In the first instance, there are real differences of scale: the levels of control reached by the state within North Korea far surpass those in, say, Soviet Romania, Hungary or Poland. Kim Il-sung and his son Kim Jong-il have 'managed to out-Stalin Stalin himself' (Lankov, 2013, p.34). The totality of control and the cult of personality that came with it were said to have deeply impressed Romanian leader Nicholai Ceacescu on a visit to North Korea, so much so that he sought to replicate these in Romania, with disastrous results.

\section{Managing control}

How has the North managed this feat of civil control? Why has it not, for example, joined the ranks of Romania, Syria or Tunisia? How, for that matter, did it escape the fall of the Eastern Bloc states and the USSR in 1991? Why has it not suffered civil disobedience and rebellion? According to Lankov, the priority of the regime is political control, which is secured through a number of mechanisms. The Korean Worker's Party (KWP) permeates society as a tool of both indoctrination and social control, dominating the lives of its citizens from cradle to grave. Work and travel within the country are tightly controlled by the regime (Lankov, 2013, p.38), though these restrictions were weakened during the famine (1996-1999). Perhaps differently from the above-mentioned autocratic states, North Korea regulates information in an extreme manner. While the Eastern Bloc was permeated by Radio Free Europe, and television signals from the West, Pyongyang tightly restricts all media inside the country. Radios and televisions have pre-set stations and there are even periodic 'inspections' to ensure that people are not tampering with the settings. Unlike in the Magreb, where social media usage has been widespread, North Korea restricts Internet usage to a narrow band of society, usually those within the security services or bureaucracy (Lee and Jang, 2009), and even they are carefully monitored. Indeed, it would appear that the regime has taken great care to ensure that the only source of information in the country is the state news agency, the Korean Central News Agency, ${ }^{5}$ in which all successes are credited to the regime, while all failures are blamed on foreign powers.

Zumwalt argues that this 'experiment in mind control' combined with hunger and poverty makes it nearly impossible for the population to consider rebellion or to be swayed by liberal-influenced social movements from abroad (Zumwalt, 2012, p.179). Cha agrees and, in a superb analysis of the factors that led to the Arab Spring (Cha, 2012, pp.430-447), shows the differences between Arab states and North Korea, looking at median income disparities, mobile phone usage, access to social media and ability to travel internally. He also looks at access to nongovernment regional news agencies (such as Al Jazeera), and the lack of a large politically active diaspora. Despite this Orwellian level of information control, Cha indicates that the regime is aware of these external events. During the Arab Spring (little of which was reported within the country), tanks and troops were amassed in urban centres, universities were shut down and students sent to work units, while all computers, MP3 players, flash drives and mobile phones were inventoried by the government. Even 
partitions in restaurants were removed to prevent 'private gatherings' (Cha, 2012, p.445). Perhaps most Orwellian of all, North Koreans are heavily indoctrinated from a young age, a form of control that lasts their entire lives. Not only do they lack the tools to rebel, and the information, perhaps they lack the ability to conceive of rebellion.

\section{Ideology and indoctrination}

North Korea's ideology is known as Juche, which translates roughly into 'self determination' or 'self-reliance' and echoes Maoist slogans during the Great Leap Forward. It is, according to Cha, the basis for regime legitimacy and control (Cha, 2013, p.60). It consists of four formal tenants: (1) man is the master of his fate; (2) the master of the revolution is the people; (3) the Revolution must be pursued in a self-reliant manner; and (4) the key to Revolution is loyalty to the supreme leader, or Suryong, Kim Ilsung (Cha, 2013, p.37). Although Juche agrees with classical Marxism/Leninism that history is an account of the struggle between capitalists/imperialists and labour, it disagrees ${ }^{6}$ on the material determinism of Marx, substituting a Hegelian power of the will and 'thought revolution'. This difference was emphasized after the 1990s collapse of communist states in Eastern Europe, when North Korean propaganda invoked the slogan urisik sahoejuui, or 'our style socialism'. Armstrong argues that this style of socialism is in reality quite flexible, allowing the regime to interpret and reinterpret as it sees fit. It has used this both to defend the domestic status quo and to make space for limited economic reforms, through the means of an ideologically loyal population. Ultimately, this is because the overriding function of Juche has less to do with revolutionary socialism and more to do with the nationalist struggle for freedom from foreign interference (Armstrong, 'The role and influence of ideology'). Zumwalt agrees with this but argues that Juche's declared intention belies its real purpose, which is to maintain security for the regime. His interpretation is that even the nationalist element of Juche is really just about social control. After all, he points out, its 'madcap economic principles' have in fact led the North to depend more on the outside world for aid largess. Zumwalt points out that the North Korean academic most associated with the creation of the concept Juche, Hwang Jong Yop, defected to the South after arguing with Kim Il-sung on the impact of Juche on the country.

\section{The cult of leadership}

All of the reviewed authors agree that the cult of leadership is an intrinsic part of the ideology, linking loyalty to the leader as part of the nationalist-revolutionary dogma. As explained by Snyder (1999), the mythmaking around the leadership has immense ramifications for loyalty by the population to the ruling Kim family. They did not merely create the revolution; they are its greatest defenders.
Similarly, they do not merely lead the state, they are the state,

to echo Louis XIV. And finally, they are not defenders of Korea; they are responsible for forging modern Korean. History as taught in the North Korean school system deifies Kim Il-sung and celebrates his role in forging the revolution against the Japanese colonial ruler as well as against the modern American imperialist. Indeed, it compares Kim Il-sung with Tan'gun, the mythological founder of the Korean people, by intertwining his personal biography and that of his family line with historical moments of foreign invasion. According to these accounts, Kim's great-grandfather led the defense of the fortress from the General Sherman, an American gunboat that sailed up the Taedong River in search of trade in 1866 . Cha agrees, stating that this has allowed the North to 'own the nationalist narratives between leaders of the Korean Peninsula' (Cha, 2013, p.34), putting South Korean leaders into the category of American puppets. As Lankov points out, this mythmaking completely whitewashes Kim's own foreign origins, as a Chinese-trained guerilla, whose initial rise depended on Soviet intelligence. Snyder states that:

The eulogizing of Kim Il-sung's great-grandfather emphasizes the influence of history on the formation and development of nationalism of the DPRK through the revolutionary ideology that has its roots not only in socialism, but also in the Japanese colonial period and even in traditional Korean governance and polity. (Snyder 1999, p.18)

This link between the past and the present is clear, according to Bruce Cumings, who invokes the principles and rigid structures of neo-Confucianist Jeosan Dynasty Korea to explain North Korean political culture. The link between leader and family, a form of corporatism, is also made, with the leader playing the part of father to society's children. By this reckoning, each individual knows their place within the family/society and is expected to revere and follow the father/leader. Not only is disobedience synonymous with rebellion, it threatens the entire fabric of society.

Although both the Soviet Union and the People's Republic of China had leadership cults around Stalin and Mao, neither of these cults survived the men themselves, whereas the North Korean version is tightly bound up with the Kim dynasty and is passed down through 'succession'. The levels of iconography around Kim Il-sung are impressive even by Stalinist standards. The build-up of the cult of leadership of Kim Il-sung was the achievement of his son and successor Kim Jong-il, who led a government agency known as the ' $4-15$ ' Creation Group. During the 1970s and 1980s, Kim ordered the construction of 12000 statues and monuments in his father's name. This culminated in the 1972 Great Monument, a giant US\$800 million, 21-meter gilded statue. (According to legend, the 
gold leaf was removed after Deng Xiaoping criticized its extravagance in 1977). One thesis for the son's deification of his father was that it was a shrewd way of guaranteeing his succession. He was making the Kim family line sacred to the nation and pushing aside other candidates, such as his uncle Kim Yong-ju. Nor was he content to press this deification on just the elite and governing class. Kim family iconography pervades all levels of society, and all schools, offices and private homes are required to have portraits of the 'Great Leader' (Kim Il-sung) and the 'Dear Leader' (Kim Jong-il). Their images must be treated with respect and cleaned regularly. The media often extols the virtues of those who at great peril and sacrifice save the portraits from flooding, fire or other catastrophe. One celebrated example, cited in the KCNA, was that of Kang Hyong-Kwon, who lost his 5-year-old daughter in flooding in 2007 by hanging onto the portraits. As Lankov argues, this is iconography at its most extreme (Lankov, 2013, p.34).

This neo-Confucian stratification finds resonance in Songbun, North Korea's class system laid down by Kim Il-sung in 1967. Comprising three groups (and various subcategories), the system defines membership to each group according to ideological loyalty to the state (and to the Kim family), setting the highest group as the politically loyal 'core class' ( 25 per cent of the population). Below this is the 'wavering class' ( 50 per cent of the population) and below that is the 'hostile class' ( 25 per cent of the population). These latter individuals may have family members in the South, or have ancestors who were landowners or administrators during the Japanese colonial period (Lankov, 2012). Compared with the 'apartheid' system by Robert Collins (Collins, 2012), these classifications are used when an individual is being considered for work, housing and travel permits. The top 25 per cent are considered for leadership roles and for membership to the KWP and are rewarded the most in terms of resources. This division of society into either assets or liabilities binds the top class to the Kim family. Those who are in the bottom class are often discriminated against in terms of these resources, and find it impossible to marry outside their class. Such preferential treatment extends to children and offspring (Oh, 'Political classification and social structure in North Korea') and it is said to be difficult to improve one's songbun. Committing political crimes, however, can lead to instant songbun demotion and the imprisonment of individuals and three generations of their extended family. It is this explicit threat to punish extended members of family that discourages dissent. Who would dare to revolt knowing that not only would one's children be punished, but also one's parents?

Ideological indoctrination begins early in the North Korean education system and continues into the workplace throughout adult life. School education involves a mixture of academic studies such as mathematics, music and the arts, with state history and the lives and thoughts of Kim Ilsung and Kim Jong-il. Although morality and history are taught mostly through the life-time achievements or theories of the Kim family, even nominally neutral subjects such as mathematics can be coloured by political teaching: one textbook poses the question, 'Three soldiers from the Korean People's Army (KPA) killed 30 American soldiers. How many American soldiers were killed by each of them, if they all killed an equal number of soldiers?' (Ford and Kwon, 2008). This indoctrination and social control do not finish at the end of school. Students are also obliged to become involved in 'volunteer' work battalions after school. The KWP has always been the regime organ that oversees aspects of mandatory work and post-work ideological sessions, and therefore has the most societal penetration. Not everyone is able to join the KWP, however, the accomplishment of which is a surefire means to better work and living conditions. The 75 per cent of the population who cannot join the KWP are instead obliged to join a trade union, associated with their workforce, or other such social group, attending thrice-weekly ideological meetings. Supplementing this method of control and surveillance finally is the 'inminban' system ('people's groups'), a type of hyper-neighborhood watch-like organization, to which everyone must belong. Membership to an inminbun comes with the housing; so those living in an apartment building will belong to that building's group. Each inminbun is usually composed of 30-40 families and is usually headed by an appointed community leader. These are usually middle-aged women, who are expected to keep an eye on all the goings-on in their group and report any suspicious activity to the police in monthly briefings. They are also expected to take note of any visitors to their building from another part of Korea and are involved in the periodic checks on radios and televisions carried out by the security services.

If ideology plays a vital role in helping the regime deal with internal pressures, how does it deal with external pressures? What is the modus operandi of the North and what is its worldview? How can a state continue to negotiate (and apparently succeed) against the will of the most powerful and wealthy nations around it? What underlies its negotiation tactics and principles and how does its larger worldview affect this? Some such as Scott Snyder in his older (but continually relevant) study Negotiating on the Edge, North Korean Negotiating Behavior (1999) examine the roots of the regime in its nationalist anti-Imperial guerilla origins to explain the logic behind its strategic and negotiating behaviour. As previously mentioned, Kim Il-sung's forces were fighting the Japanese Imperial Army, giving the regime claim to narratives around Korean nationalism. This strong sense of nationalism is also affected by doctrine associated with 
Marxist-guerilla approaches to combating larger forces arrayed against them. In other words, a state like North Korea is not only used to having larger forces arrayed against it, it may actually prefer it since this fits in both with its strategic evolution and mindset. It has developed a number of strategies that are designed to off-balance its larger foes, which are poorly understood by those Western diplomats arrayed against them at the bargaining table. It also has a maximum gains philosophy, seeing compromise as weakness.

Perhaps it is exactly this worldview that explains the decision taken by the North in the late end of the Cold War to develop its own nuclear arsenal, a form of deterrence and a means of extracting aid. But why did it choose this route, instead of choosing to rely on Chinese or Russian nuclear deterrence? Although many allege that this is due to the hyper-nationalist nature of the regime, scholars differ as to what this means. Some such as Cha believe that despite close political ties, there is little trust between North Korea and the PRC. Cha also believes that the Cuban Missile Crisis revealed the empty reality of Soviet security guarantees, as Moscow essentially 'betrayed' Havana in the crisis. Lankov, on the other hand, stresses the existence of a competitor in the South, rich and prosperous, as a defining feature in the North's decision to eschew economic reform in favor of the nuclear card (Lankov, 2013, p.148). According to Lankov, the existence of a Korean 'other' means that any compromise could lead to comparison, and eventually judgment by the Korean population. Others such as Cumings (1997) look to Korea's cultural history to explain these larger strategic decisions to eschew compromise, which might lead to vulnerability to foreign forces. The nature of the regime, according to this account, is not markedly different from the Joseon Dynasty (1392-1897) in how it approaches relations with foreign powers, a state that was but a 'shrimp surrounded by whales' ${ }^{7}$

\section{The Economic Riddle}

There is a broad consensus that North Korea developed its nuclear weapons programme due to its inability to accept economic reform. What made economic reform necessary? Three of the five books mentioned above attempt to explain the breakdown of North Korea's economy: Cha's The Impossible State: North Korea, Past and Future; Lankov's The Real North Korea: Life and Politics in the Failed Stalinist Utopia; and Chapter 6: Western Aid (by Eberstadt) of North Korea in Transition. Beginning with this structural element of the country allows some basic facts to intrude onto what is an ideologically riven landscape. North Korea's economy is by any modern reckoning a shambles. The country ranks among the world's poorest and has consistently marked negative growth. Its dependency on foreign aid, particularly from Beijing, is well known despite going against the grain of its self-stated ideology of self-reliance. Owing to its large foreign debts of \$20-\$25 billion, the result of heavy borrowing from its Communist allies during the Cold War, it is unable to gain sufficient credit for further borrowing. Neither are its debts all to friends: it has a further $\$ 6$ billion of debt to South Korea, incurred during the Sunshine Policy era (1998-2008). Worse still for its credit has been its attitude towards these debts, which has been to spend the capital and demand debt remission.

How did North Korea come to this situation? How has it managed to crash its economy and put itself into debt? If one were to predict in 1953 which of the two Koreas then just establishing themselves would be the most successful today, undoubtedly the choice would have been the North. In 1945, it had the most industrial infrastructure in Northeast Asia outside of Japan. This industrial legacy was a product of Japanese colonial planning, and in 1940 the North produced ' 85 per cent of metals, 88 per cent of chemicals, and 85 per cent of electricity in Korea at that time' (McCune, 1950, pp.56-57). As a result, transportation infrastructure was better; there was greater urbanization, and increased energy supplies. Furthermore, the country is rich in mineral deposits and resources, with large deposits of coal, iron ore, zinc, nickel and rare earth metals. ${ }^{8}$ While heavy US bombing took its toll during the war, the North was able to set about on a programme of reconstruction by securing large aid packages from both the Soviet Union (CIA Declassified Document, 1955) (\$290 million) and the People's Republic of China (\$500 million) throughout the 1950s and 1960s. By 1960, economic revitalization of the North led Kim Il-sung to promise that all North Koreans would 'eat boiled rice and meat soup, dress in silk and live in houses with tiled roofs'. Given the North's advantages, this did not seem unlikely. As recently as the 1980, for example, the DPRK's per capita exports were over twice as high as China's, but by 2007 were less than a tenth (Eberstadt, 2013).

So what went wrong? There is already a large literature on the problems inherent in the state-planned economies of the Soviet era, and while much of this research is also valid in the case of the North, it seems far worse off than many. ${ }^{9}$ Its economy is far worse off, for example, than many of the Eastern Bloc satellite states at the time of collapse in 1989. Furthermore, all writers agree that little if any of this can be blamed on US or international sanctions, which have tended to target those state organs, banks and agencies that are directly related to the nuclear programme. Certainly, the collapse of Soviet and Chinese aid in 1990 was a 'key variable' in the collapse of the 1990s. In 1985, Russia accounted for 49.5 per cent of total trade, but by 1993 this had plummeted six-fold to less than $\$ 100$ million. Worst hit was the energy sector, which had benefited from the 'friendship' discounts of 25 per cent of market prices. 
Between 1990 and 1991, oil imports dropped by half from 3.5 million tons per year to 1.5 million tons. As Cha argues, this sector had an immense ripple effect on all the other sectors: coal production slowed due to a lack of ammonium nitrate, while fertilizer decreased agricultural output. The need to irrigate fields hurt the one successful source of power in North Korea, hydropower. Although China initially boosted its aid to the North to help cover these shortfalls, by 2003 it too had put an end to patron aid and demanded cash or barter at market prices. However, it should be noted that this collapse reveals an economy already dangerously dependent on the largess of its patrons. What factors explain this dependency?

\section{History of the DPRK's economy}

There are some real differences between the three authors in explaining the collapse. Eberstadt (2013) argues that the decline was gradual after an initially strong economy, while Cha (2012) argues that Kim made five bad decisions that doomed the Northern economy from the start. We will start with Cha's thesis. First, he states, Kim Il-sung concentrated much of the post-Korean War Russian and Chinese aid in heavy industry, eschewing light industry and agriculture. For example, more than 81 per cent of resources were allocated to heavy industries such as iron, steel, mining, chemical fertilizers and oil refineries in the Three-Year Economic Plan of 1954-1956. This depleted labour from the agricultural sector to the industries and stymied the creation of a consumer sector, preventing the creation of a whole host of other related industries. As the Cold War heated up, the economy failed to rebalance; instead, the emphasis moved from heavy industry to militarization.

In North Korea, ideology was allowed to trump rational economics, North Korea's second mistake. Cha describes the Ch'ollima movement, an offshoot of the state-sponsored ideology of Juche. In essence, Ch'ollima dictated that any shortfalls in production or manpower could be made up in 'revolutionary zeal', that workers could overcome systemic inefficiencies, poor planning or lack of innovation with longer hours and other such sacrifices. Although this had short-term effects of overcoming difficulties, it avoided the development of new technologies, which would contribute to greater output. The third mistake made by North Korea was to get into debt, spawned by its massive military modernization programme from 1968 to 1979. Despite having less than half the population of the South, North Korean spending exceeded that of the South and its land army rose from 485000 to nearly double that by 1980 , building double the number of heavy tanks and artillery than US-ROK forces. According to Eberstadt, North Korea was operating on something akin to a totalwar footing, maintaining a cadre of a 1.2 million non- civilian male population - a percentage of the population in the military only seen in the United States in 1943 (Eberstadt, 2013).

Thus, between 1970 and 1975, North Korea borrowed around $\$ 1.2$ billion from countries such as France, the United Kingdom, Japan and Czechoslovakia, and having failed to service the debt, has seen this rise to $\$ 12.5$ billion from interest. Few expect Pyongyang to repay them, and North Korea's international credit rating is approximately zero (Eberstadt, 2013). The fourth bad decision stemmed from the success of South Korea, particularly around the period of the 1988 Seoul Olympics, from which - Cha states - Pyongyang developed 'Olympic envy'. From 1987 to 1989 , North Korea spent somewhere between $\$ 4$ and \$9 billion on building 160 major facilities for the 1989 World Festival of Youth and Students in and around Pyongyang, among them 12 athletic facilities. In addition, they embarked on a number of huge, wasteful public works projects: a tideland reclamation project, the West Sea Dam (the largest in the world according to Zumwalt), the hydrothermal T'aech'ŏn, a failed vinylon ${ }^{10}$ complex of factories and the Sariwonn Fertilizer Plant. This hollowing out of the North Korean economy, draining it of manpower, financial reserves and energy, took place just as the Cold War was coming to a close, bringing with it the sudden demise of Soviet and Chinese aid.

Fifth, once collapse was imminent, Cha states, the North turned to the international community for help, but rather than using this aid as a supplement to government attempts at market reform, it merely consumed the aid as a form of revenue, while still maintaining its costly military programmes. In contrast to these broad themes, Eberstadt is more specific in his critique: according to him, the North's secrecy undermined its own statistical system, by allowing for falsification and politically motivated doctoring. The lack of real figures is the death knell for any centrally planned economic system. Then he argues that there are indications that the planning process itself has become compartmentalized, irregular and ad hoc. The lack of a national economic plan since 1993 goes some way to legitimating this assertion. Eberstadt also refers to the 'relentless war against the consumer sector', a reference to the unnaturally small consumer industrial base of the North. According to this account, the lack of a consumer market eliminates the 'inducement goods' that act as motivation for workers to earn and save. While North Korea has a history of consumer sector initiatives (see the August Third Consumer People's Consumer Goods Production Movement in 1984) this has usually followed the way of most economic reform initiatives. This was further exacerbated by the lack of financial intermediation, or institutes such as banks, credit markets, and so on. North Korea's efforts to generate revenues in illicit trade have also further marginalized it from the international economy, and its 
involvement in the smuggling of counterfeit currency and narcotics is now beyond debate.

\section{Famine}

The catalyst for the breakdown in North Korea's public distribution system (PDS) and resulting famine was the 1995 summer rains. Following the drop in Soviet and Chinese energy supplies, North Koreans had struggled through the harsh winter by cutting down trees for firewood. This deforestation meant that the land was highly vulnerable to flooding. Four western provinces were affected; more than 100000 families were displaced and 988 422 acres of arable land were destroyed. Damage to the agricultural sector was profound: more than 70 per cent of the annual rice harvest and 50 per cent of the maize harvest were ruined. Worse still, between 1.2 million tons of emergency grain reserves were lost due to their storage in underground silos, which flooded in the rain. In September 1995, Pyongyang realized the gravity of the situation and made an international appeal for help. Given its bad international credit rating, it could not borrow, and had to depend on the World Food Program, UNICEF, the World Health Organization and the Red Cross. Despite this rational step, many organizations found it difficult to operate inside the country, which imposed heavy restrictions on aid implementation in-country.

Although it would seem that the cutting of energy supplies and the following rainfall of 1995 were the cause of the collapse of the North Korean economy and PDS, Cha makes a convincing case as to why this was not the case. First, the PDS had already begun to shrink pre-1990. In the 1960s, for example, white-collar workers were entitled to $700 \mathrm{~g}$ of food per day, but by 1987 this was down to 547 g. In 1992, three years before the famine, Pyongyang initiated a 'Let's Eat Two Meals Per Day' campaign to help with food shortages. Furthermore, by stressing 'selfreliance' in the agricultural sector, the regime relied heavily on chemical fertilizers and continuous cropping, leading to soil erosion over time. Given the mountainous topography of North Korea and relatively short growing season, this insistence on self-sufficiency was doomed from the start. Finally, Cha argues that the regime's response to the famine was completely inadequate; while the population suffered, perhaps losing 600000 to 1 million lives, the North continued to spend 25 per cent of its GDP on the military. Essentially, the regime looked to the international community to bankroll its system.

So what of the July 2002 market liberalization reforms undertaken by the regime? Have they or the subsequent development of special economic zones and non-state markets encouraged change and reform from within the system? What of the joint ventures between Pyongyang and Seoul, the Kaesong Industrial Zone and the Kumgang Mountain Complex? Cha, Lankov and Eberstadt agree that unfortunately none of these elements have made any real impact, and to varying degrees that failure lies with the regime's inability to accept economic growth in exchange for political weakening. Lankov goes further and explains what makes North Korea so different from China or Vietnam. He states that the fact that the North sits next to a state that speaks the same language and has a competing claim as the 'real Korea' is a major obstacle to opening up to reform. The differences are stark, with some claiming that the South enjoys a per capita living 16 times that of the North. This is considered the largest per capita income gap between any two countries that share a border ${ }^{11}$ (Lankov, 2013, p.112). The superiority of its hold over that of the south would be revealed. South is doing far worse would be revealed. Such a revelation, even if coupled with a promise of economic reform and growth, would lead to immense delegitimization of the regime and instability. Given the perceived stakes in opening up to reform, one sees the logic behind Pyongyang's repeated failure to implement promised reforms. The stakes are simply too high. According to one account, a high-level North Korean bureaucrat was unusually frank to a Western diplomat, stating, 'The human rights and the like might be a great idea, but if we start explaining it to our people, we will be killed in no time' (Lankov, 2013, p.115).

One can see, for example, that the 2002 monetization of the economy was a short-term coping mechanism rather than a real wholesale shift in economic planning. Furthermore, its effects were almost being felt when the regime began rolling them back. The Special Economic Zones model has been the only model pursued with any enthusiasm by the regime, and this is because it enables Pyongyang to carry out economic activity under controlled conditions. It also enables the regime to get its hands on hard cash, which can then be used to reward the ruling elite. Gause argues that this is because of real differences of opinion within the regime on what the economy should look like. Time and time again, the regime demonstrates that its interest in reform is only short term and wastes little time in suppressing the growth of non-state markets (see the 2006-2007 crackdown), in order to re-establish the public dependency on the state-controlled PDS.

The 2009 currency re-evaluation is a strong example of this urge by the regime to suppress the growth of a middle class linked to the non-official markets. In November 2009, without prior warning to the public, the regime issued Decision No.423, issuing overnight a new currency. The exchange rate for the new won to the old was to be 100-1 and there was an upper limit placed on the amount a family could exchange (150 000 won or one month's living costs). This upper limit decimated at a stroke the savings of the growing merchant class, as they were only able to change a small portion of their amassed savings. Despite preparing 
the security services for this event, the regime was taken aback by public anger and began to loosen the currency limits within weeks of the act. Despite this loosening, they continued to ban foreign currency conversions and kept a ban on the free markets (Gause, 2011, pp.129-132) for nearly three months.

\section{The Security Riddle: A Military with a State?}

Owing to its history, and its long-standing commitment to re-unite the Peninsula, North Korea's military has always been a large part of its political structure. The Korean War is still technically in existence, as only an armistice was signed in 1953. The border separating the two countries is one of the most militarized in the world and the forces arrayed around it are a mutual deterrence. On the US-ROK side, there is a well-trained and technologically advanced force; on the DPRK side, there is an even larger Soviet-era force. While the South spends more than four times that of the North ( $\$ 27$ billion to $\$ 8$ billion), it has a much larger economy and that spending is a much lower percentage of its GDP. Despite the spending disparity, the North has double the men, double the tanks, three times the number of submarines, three times the number of landing craft and six times the number of combat helicopters. It has 1.19 million active-duty personnel with another 600000 in the reserves. Given the fact that North Korea's population is 24.5 million, this makes the country one of the most militarized societies in the world. The North has large numbers of special forces (numbering close to 200000 ) and is also equipped with the largest artillery force in the world - some 21000 systems and 2300 multiple rocket launchers, many of which are within striking distance of Seoul (Cha, 2013, p.219). Despite these alarming differences, the DPRK military is a shell of its Cold War self and many of its systems would be heavily outmatched fighting the equivalent US and ROK systems. Furthermore, a lack of gas and oil reserves means that its air force and armor forces would be stretched to capacity in any engagement lasting more than a few days. To some extent, this imbalance and its undermining of mutual deterrence was exposed in the 1991 Gulf War, when a similarly equipped military was defeated in a land war by superior US forces. One wonders to what extent this factor played a part in the push for nuclear weapons.

Despite this imbalance in conventional forces, Cha argues that the North's other weapons might lead the regime to overlook the balance of deterrence. In 2006, 2009 and 2013, Pyongyang successfully tested a nuclear weapon which of course has been the predominant issue of concern for the United States and its allies. In addition to its nuclear programme, however, the North also has a strong missile programme, and a large biochemical weapons programme. As most attention has been on the nuclear weapons programme, North Korea's missile programme has gone unchecked over the past 20 years. During that time, the DPRK has been attempting to develop a ballistic missile capable of reaching long distances, including the continental United States. While it has not developed this yet, and has yet to develop reentry technology, its immense progress from a Scud missile baseline in the 1980s has been impressive. As Secretary of Defense Robert Gates acknowledged, it is only a matter of time before the DPRK develops the capability to reach US targets in Japan and Hawaii. Regarding its biochemical weapon stocks, Pyongyang is said to have between 2500 and 5000 metric tons of various agents, including sarin, mustard gas, VX gas, phosgene, cholera, plague and anthrax. ${ }^{12}$ As Cha makes clear in his compelling account of US policy on the North, Washington's worries are two-fold: first, the North will weaponize these agents for long-range delivery, and second, it might pass the systems on to other rogue regimes in order to get hard currency. Indeed, both Syria and Iran are said to have benefited from North Korea's missile and biochemical weapons programmes (Cha, 2012, pp. 223-235).

Roerig argues that like all communist regime militaries, the KPA was tasked with protecting the party, the revolution and the state, but that this gradually changed after the death of Kim Il-sung. The development of North Korea into a military state or military-run state took place under Kim Jong-il during the second half of the 1990s. According to Gause, this 'military-first' policy or sŏngun chongch'I was the direct result of the inability of the bureaucracy and party to overcome the failing economy left by the collapse of Sino-Russian aid. As these problems accumulated, with the onset of the famine of 1996-1999, a sense of crisis permeated the country, and the only ministry that seemed still able to function was the army. In 1995, Kim unveiled the new policy and in 1998 these changes were formally adopted into the constitution at the 10th Supreme People's Assembly: the National Defense Commission (NDC) and Cabinet were elevated above party control, with the former becoming the highest decision-making body in the land.

\section{Clausewitz's trinity}

Despite this apparent demotion of the party, Gause argues that the party apparatus did not simply wither away; it remained important to Kim, and he used it for judiciary, intelligence and economic policy implementation (Gause, 2011, p.24). However, its role within the governing structures in Pyongyang was severely restricted. An alternative explanation for the military-first policy was that Kim wanted to secure the loyalty of the military in the wake of the fall of the European communist states. If one takes the Clausewitz trinity of people, government and military, it is clear that revolution can only happen when the government has lost the support of the military. Viewed 
historically, there is much to recommend this interpretation of Kim Jong-il's motives. After all, Gorbachev and other reformers had all risen from within the party, which made it suspect in the eyes of Kim. Weakening the party may be bad for the vanguard of revolution, but clearly losing the support of the military would be disastrous. Such reasoning would be far from academic for Kim. After all, there were a number of instances, some very close to him, that would have stood out as lessons. The close relationship between the Kim and Ceaușescu regimes has already been described. According to Kenji Fujimoto, the Kim family chef and one of the few sources of anecdotal information on the family, the fall of Ceaușescu was watched closely on CNN by Kim and his aides. The desertion of the army to the rebellion had been crucial in Ceausescu's downfall. Likewise, the desertion of key Soviet forces in the summer of 1991 around the White House from the hardliners' side had been the catalyst for the end of the Soviet Union.

\section{Conclusion}

Nearly every year sees North Korea in the news, often at the forefront of yet another regional crisis. This year, 2013, has been no exception, with a large amount of international media coverage of the most recent crisis, which began with the North's satellite launch in December 2012 and was followed by a UNSC Resolution in January. This in turn was followed by the North's third nuclear test in February, US-ROK military exercises and the closure of the Kaesong Industrial Zone. Despite the alarmist tone of the coverage, the escalating levels of Northern rhetoric, and the use of B52 bombers in Foal Eagle $2013^{13}$ by the United States, there seemed little new to those habituated to North Korean crises. Indeed, 2013 iteration seemed to play itself out in a familiar and formulaic manner, repeating a cycle that was evident in the 2010 crisis, the 2009 crisis, the 2006 crisis and the 2002-2003 crisis. The only difference - thus far between this time and previous iterations has been the response by the People's Republic of China, which has appeared to take a harder line over the third test by supporting UNSC sanctions and stopped a number of Chinese banks from dealing with the North.

Nearly all of the authors agree that North Korea as it is cannot continue forever. China's moves indicate that while it is willing to prop up the regime, it does not see this as a blank cheque. It wants its aid and economic support to count as leverage in Pyongyang, and signs of its unhappiness at the latest nuclear test are becoming more apparent. It is not able to turn the aid off, fearing total collapse, but it can squeeze the regime to indicate its displeasure. According to Cha, the end is near. While none of the indicators for revolution exist in the North, authoritarian systems are inherently unstable. He lists a number of instances of dissent and coup attempts, which reveal the innate fragility of the regime behind its secure façade (Cha, 2012, pp.452-453). This, combined with growing Internet and mobile phone usage, will open the trickle of information to a flow. There are already some reports that this is the case, with some of it analyzed in the 2012 InterMedia report A Quiet Opening: North Korean in a Changing Media Environment. Further anecdotal evidence exists around South Korean films (such as '71: Into the Fire') gaining popularity through the illicit trade of DVDs in the markets. In an East-West Center Report, Double-Edged Sword: Information Technology in North Korea, Scott Thomas Bruce argues that developing an intranet and mobile phone network means that the North has made a fundamental shift away from a state that sees information as a threat and a state that sees it as a necessary tool to escape from its economic troubles. Echoing Cha, he believes that the seeds of change are in such developments.

Like Cha, Lankov also believes that the regime is doomed, but that not only will this be a long-drawn-out event, but that it is in everyone's interest to ensure that it is drawn out. Of the five books analyzed, only Lankov looks at some of the post-collapse scenarios and makes interesting policy suggestions. Drawing on the historical experience of Germany, he shows how the cultural and monetary differences between East and West Germany were slight compared with the gulf between North and South. Unmanaged swift collapse is likely to cause one of the century's greatest humanitarian disasters, demanding the attention of the UN and its relevant humanitarian organizations. The combination of refugee flows and the collapse of the PDS, and large armed groups of loyalists wandering the countryside could lead to the perfect storm. Borders would be shut to prevent large flows of people into China and South Korea, throwing up large refugee camps. Then there are the problems around securing nuclear and biochemical weapons, something that elite US and ROK troops would have to do within the first $72 \mathrm{~h}$ of collapse. Even if that chaos is stemmed, and Chinese and American diplomats are able to agree on a unification scenario that satisfies both of their interests, there are still other costs to consider. Estimates for unification costs range between $\$ 1.5$ and 2.5 trillion, significantly larger than the current GDP of the South. Where would Seoul get that money? Certainly, Tokyo, Beijing and Washington would be pressed to help Seoul, as would other attendant organizations such as the World Bank and IMF. Costs would not only be high for infrastructure. There would be the re-training and re-integration costs for middle-class trained North Koreans. Teachers, engineers and even medical doctors from the North would find their knowledge out dated in today's computerized world. If the new Korea is not to be divided into two mutually resentful classes, such a re-integration would have to take place swiftly, over a decade or so. This would require immense capital and training manpower. 
Very few issues in the Asia Pacific region are as pressing as that of North Korea, not merely because of the nuclear issue, but also because of the epic proportions any collapse scenario involves. While collapse has been predicted many times for the North and failed to materialize, we should not run the opposite risk of thinking it impossible. As the Eastern Bloc, Egypt, Libya and Tunisia reveal, prediction of anti-government social movements is still in its infancy. This should make the study of North Korea a more urgent priority for all of us. We would be doing the people of North Korea a disservice not to plan.

\section{Notes}

1 It ranks 7th out of 7 (lowest possible) in Freedom House's Freedom in the World Index, and is in the 0th percentile in the World Bank's Voice and Accountability Index (Cha, 2013, p.8).

2 North Korea's most senior defector to the South.

3 For a broader engagement on the literature on North Korea's coming collapse, see Levin (1997), FosterCarter (1998), Eberstadt (1999), Wampler (2006).

4 For more on this, see the New York Times op-ed from April 2009, entitled 'North Korea's Nuclear Blackmail', authored by Henry Kissinger; The Independent's 'North Korea returns to its game of nuclear blackmail', May 2009; and more recently the National Review Online's 'Responding to North Korea's Nuclear Blackmail' from March 2013.

5 The Press Freedom Index 2013 was accessed from the Reporters Without Borders Website http://en.rsf.org/ press-freedom-index-2013,1054.html on 14 July 2013. The report shows that the DPRK ranks 178 of 179 in the Reporter's Without Borders 2013 Press Freedom Index.
6 The history of the DPRK and the USSR and PRC is one of ideological competition and post-Stalinist disappointment with Soviet 'revisionism'. According to Lankov, relations between Pyongyang and Moscow became so bad at one point that the North Korean Ambassador to Moscow defected to the USSR, an unprecedented event in the history of Cold War. This disenchantment soon switched to Beijing during the Cultural Revolution when the DRPK moved back to close relations with Moscow, finally ending in the 'Equidistance' policy, which continued until the 1990s (Lankov, 2012, pp.16-20).

7 This expression is often used by Koreans to describe their situation among four great powers, Russia, China, Japan and, most recently, the United States.

8 According to Cha, there are ' 100 billion metric tons of limestone, 14.7 billion tons of coal deposits, 6.5 billion tons of magnesite, 3 billion tons of iron ore, 12 million tons of zinc, 1.2 million tons of nickel, and substantial deposits of silver and gold' (Cha, 2012, p.111).

9 According to Lankov, these included 'distorted price information, lack of incentives for innovation and quality improvement, and an ingrained inability to handle data efficiently' (Lankov, 2013, p.71).

10 Vinylon is a material similar to nylon, which is prohibitively expensive for most states to make. It is perhaps unique to North Korea.

11 To put these figures in perspective, East and West Germany only differed by a 1:3 ratio.

12 'North Korea's Chemical and Biological Weapons Programs', International Crisis Group Asia Report No.167 (June 18, 2009), p.7.

13 Annual exercises held by the militaries of the United States and ROK.

\section{References}

Armstrong, C.K. (2012) Trends in the study of North Korea. The Journal of Asian Studies 70(2): 357-371.

Armstrong, C. (2013) The role and influence of ideology. In: S. Snyder and P. Kyung-Ae (eds.) North Korea in Transition. Plymouth, UK: Rowman \& Littlefield Publishers.

Bruce, S.T. (2012) Double-Edged Sword: Information Technology in North Korea. Honululu, HI, USA: East-West Center.

Cha, V. (2012) The Impossible State: North Korea, Past and Future. New York: Harper Collins.

CIA Declassified Document (1955) Soviet economic assistance to its Sino-Soviet Bloc Countries. 13 June, p.73, http://www.foia.cia.gov/sites/ default/files/document_conversions/89801/DOC_0000496610.pdf, accessed 16 July 2013.

Collins, R. (2012) Marked for Life: Songbun: North Korea's Social Classification System. Washington DC: The Committee for Human Rights in North Korea.

Cumings, B. (1997) Korea's Place in the Sun: A Modern History. New York: Norton.

Eberstadt, N. (1999) The End of North Korea. Washington DC: AEI Press.

Eberstadt, N. (2013) Western aid: The missing link for North Korea's economic revival? In: S. Snyder and P. Kyung-Ae (eds.) North Korea in Transition. Plymouth, UK: Rowman \& Littlefield Publishers.

Ford, G. and Kwon, S. (2008) North Korea on the Brink: Struggle for Survival. London: Pluto Press.

Foster-Carter, A. (1998) North Korea: All roads lead to collapse - all the more reason to engage pyongyang. In: M. Noland (ed.) Economic Integration of the Korean Peninsula. Washington DC: Institute for International Economics.

Gause, K.E. (2011) North Korea under Kim Chong-il: Power, Politics, and Prospects for Change. Oxford, UK: Praeger.

Kretchun, N. and Kim, J. (2012) A Quiet Opening: North Korean in a Changing Media Environment. InterMedia report 2012.

Lankov, A. (2013) The Real North Korea: Life and Politics in the Failed Stalinist Utopia. Oxford, UK: Oxford University Press.

Lee, H. and Jang, S. (2009) The internet dilemma and control policy. Korean Journal of Defense Analyses 21(3): 279-295.

Levin, N.D. (1997) What if North Korea survives? In: Survival. London, UK: Taylor \& Francis. 
McCune, G. (1950) Korea. Cambridge, MA: Harvard University Press.

Oh, K. (2003) Political classification and social structure in North Korea. Brookings website http://www.brookings.edu/research/testimony/2003/06/ 05northkorea-oh, accessed 18 July 2003.

Park, K. and Snyder, S. (eds.) (2013) North Korea in Transition. Plymouth, UK: Rowman \& Littlefield Publishers.
Snyder, S. (1999) Negotiating on the Edge: North Korean Negotiating Behavior. Washington DC: United States Institute of Peace Press.

Wampler, R.A. (ed.) (2006) North Korea's Collapse? The End is Near Maybe. National Security Archive Electronic Briefing Book No. 205, posted in October 2006.

Zumwalt, J.G. (2012) Living the Juche Lie: North Korea's Kim Dynasty. Florida: US Adducent. 